\title{
Does Knowledge Management Enhance Human Resource Practices in Marketing
}

\author{
V. R. Palanivelu ${ }^{1}$ and E. Saranya ${ }^{2}$ \\ ${ }^{1}$ Prof \& Head, Department of Management Studies, Periyar University, Salem \\ ${ }^{2}$ UPDF, Department of Management Studies, Periyar University, Salem
}

\section{ABSTRACT}

Purpose- The paper was aimed to make a knowledge management design for market plan which is going to fulfill the market needs and strategies which is move on with the customers and from the customers. In this paper the dynamic and interactive marketing strategy is under the concern of human resource practices to scrutinize the methods for effective marketing. Design/ Methodology/ approach- Despite its importance of organizational growth, there is some lacking knowledge in the marketing field. This paper will clearly give the ideas about the knowledge centric human resource practices for the better understanding for the same. Research implications- This article discuss the linkages between the marketing and knowledge management which suggest the research potential for the product reach to the market. Social implications- This paper encourages human resource to consider the marketing needs of organization.

\section{KEY WORDS: HUMAN RESOURCE PRACTICES, ISSUES IN MANAGEMENT, MARKETING STRATEGY, KNOWLEDGE MANAGEMENT.}

\section{INTRODUCTION}

In recent views due to the rapid development in both technology and innovation, we are facing more struggles to sustain in the competitive business world. This is also due to the arrival of new born companies in the automobile business world. They are proving tough competition by implementing innovative strategies in the emerging marketing field. Even though they are implementing innovative strategies, they are unable to sustain in the emerging marketing. This is because of the poor knowledge management in both customer requirements and marketing.

\section{ARTICLE INFORMATION}

Received 10th Oct 2020 Accepted after revision 29th Dec 2020 Print ISSN: 0974-6455 Online ISSN: 2321-4007 CODEN: BBRCBA

Thomson Reuters ISI Web of Science Clarivate Analytics USA and Crossref Indexed Journal

\section{Clarivate
Analytics}

NAAS Journal Score 2020 (4.31)

A Society of Science and Nature Publication,

Bhopal India 2020. All rights reserved.

Online Contents Available at: http//www.bbrc.in/

Doi: http://dx.doi.org/10.21786/bbrc/13.15/41
Many researchers are being involved in the research to find the solution for these problems. This study is also based on the below- mentioned hypotheses. For this research, we have taken nearly 50 samples in the various automotive environments in and around the Coimbatore District based on their age and living pattern. In this study, we are in focus with ten basic issues on the basis of customer point of view. On the account of the customer evaluation, all the statement of the issues was analyzed. After the analysis, we found the solutions for the issues by correlating the issues with the data. In this paper, problem statement, objective, methodology, research hypothesis, analyzing tools, findings, suggestion have been discussed. Finally, we come to the conclusion.

Literature Review: The important reason for knowledge management is that it gives a certification of an organization to attract and retain talented people. Secondly the engagement of employee towards their work which is subjected to the technology and benefiters (Morten, 2005). Retaining and engaging. When combined these two it acts as the important factor of the company success (Hughes \&t Reg,2008). For increasing knowledge management, talent management gives more strength 
(Whelan \&t Caracary, 2011). The important tool of competitiveness is knowledge management and also it is a extraordinary asset of a organization (Kiessling $\mathrm{Ct}$ Harvey, 2006).

Employees knowledge skills, capabilities are the main predictors of a competitive advantage of a firm (Colling \& Mellahi, 2009). Youngsters always wants to buy a branded product (Singh \& Madan, 2020) which reveals the updated technology plays a vital role in every type of sector. Ignoring customer knowledge management may cause companies spending billions of dollar in a year. Partial knowledge of CKM strategies in many marketing persons spoiling the customer engagement. Active competences and technical resourcefulness encompassed the business. (Lomas, n.d, 2016)

Applicability of KM in marketing always motivating the employees to be engaged in work. KM process having the very stable relationship between the company performance in the market. Eminence routine and operative performance followed by pioneering act has the stoutest impact with KM process.(Al et al., 2019) Business environment has been changed continuously depending upon penetrating competition, consumer penchant, hasty technical updating, profitability and market sustaining. For the effectful marketing knowledge management is needed. It promotes innovation over knowledge procurement, sharing and application. Its impact reflects on the performance of an any organisation (Muddaha Et Kheng, 2018).

Talent and Knowledge are most necessitated aspects in every organisation nowadays foe every departmental functioning. Many of the firm has started well but not continuing the same appropriately. Repeated training and development for the executives provides career path for a individual as well as the prompt success of the company too. It also creates the better understanding job description and rewarded as best performers. The important rule of attaining the goal of an organisation should be tapping the right person with right knowledge at the right period which developing as self and to firm (Sanjana et al, 2020).

Giuesppe festa et al (2020) in "Knowledge management in international marketing processes-the case of Made in Italy" explained about the role of local and national entrepreneurial collaboration. They framed the factors such as history, style and talent of business aspects and found how come that been a essence and base of Italian territory capitalism. They have taken the small and medium enterprise as sample. They resulted that expanding international level was more complicated but 'glocalism' drives the potential success in strategies of internationalization. They concluded as territorial capitalism is a unique component in reputation aspect of capital worldwide.

Statement of Problem: The employees are facing many problems due to the lacking and poor knowledge management in the competitive marketing field. This paper deals the problems which really affect the effective marketing. There are fifty employees examined for this study who working in different Automobile Industry in and around Coimbatore District. After the crystal clear analysis, we found the following statements.

- $\quad$ The employees are unable to understand the current marketing strategy. This is due to the poor knowledge in business management.

- They focused only to finish the target within the time frame.

- They never consider the customer needs due to the pressure given by the higher officials like team head, sales manager etc.,

- $\quad$ They are unable to make innovative marketing strategy due to the lacking in customer requirements.

- They are very weak in knowledge about the competing products in their field.

These are the problems which really affect the effective marketing ability of the employees.

\section{Objectives}

1. To make knowledge management design for market plan which is going to fulfill the market needs in an automobile industry in Coimbatore district.

2. To improve the ability of the employee by suggesting an innovative marketing strategies.

3. To provide modern human resource practices for the better understanding of the employee about the marketing and customer requirement.

\section{METHODOLOGY}

50 employees have been randomly selected as a sample for primary data who was in the automobile industry. Secondary data collected from various journals, net sources and book articles.

\section{Hypotheses}

H1: There is a significant relationship between the knowledge centric human resource practices with the customer needs.

H2: There is a significant relationship between existing knowledge management and customer satisfaction.

Table 1. Reliability Statistics

\begin{tabular}{|l|c|c|}
\hline $\begin{array}{l}\text { Cronbach's } \\
\text { Alpha }\end{array}$ & $\begin{array}{c}\text { Cronbach's Alpha Based } \\
\text { on Standardized Items }\end{array}$ & N of Items \\
\hline .807 & .724 & 10 \\
\hline
\end{tabular}

By doing reliability test the data reliability have been examined to proceed further of the research. Above table revealed the analysis result of Cronbach Alpha and standardized item value respectively .807 and .724 respectively which shows the data has satisfactory internal consistency. 


\section{Analysis}

The below statements were used as a factors for the statistical study.

\begin{tabular}{|l|c|}
\hline CODE & FACTORS \\
\hline QS1 & \begin{tabular}{c} 
Market value of the vehicle. \\
\hline QS2
\end{tabular} \\
\hline QS3 & Vehicle price range within market value \\
\hline QS4 & Low-fuel consumption engine. \\
\hline QS5 & Mileage of the vehicle. \\
\hline QS6 & $\begin{array}{c}\text { Knowledge of the employee } \\
\text { about the vehicle. }\end{array}$ \\
\hline QS7 & $\begin{array}{c}\text { Knowledge of the employee } \\
\text { about the other surviving products. }\end{array}$ \\
\hline QS8 & Promise fulfillment by the company. \\
\hline QS9 & $\begin{array}{r}\text { Company's affable relationship } \\
\text { with customer }\end{array}$ \\
\hline QS10 & Satisfactory level of customer \\
\hline
\end{tabular}

\section{Factor analysis}

Principal Component Analysis: Extraction Method: Each factor has explained the total variance with the result of Eigen value. Every factor attributes the percentage of total variance. Principal Component Method, which is one of the popular methods used in EFA for considered to determine the minimum number of factors with minimum data variance.

Varimax Kaiser Narmalization: Rotation Method: Identifying statements with large loadings in same factors facilitated the factors interpretation. In terms of high loading statement the factors can be interpreted. Among 10 factors, 3 individual factors contribute more towards effective knowledge management in marketing. For all the analysis of the samples, the code of the statements was used and also those were taken for the correlation and all other factors were failed towards the same.

The factors are;

1. QS1 - Market value of the vehicle.

2. QS2 - Price of the vehicle within the market value.

3. QS4 - Low-fuel consumption engine.

The correlation among the variables Market value of the vehicle, Price of the vehicle within the market value, Design of the vehicle, Knowledge of the employee about the vehicle, Promise fulfillment by the company and Customer satisfaction has done.

\begin{tabular}{|c|c|c|c|c|c|c|c|c|c|}
\hline \multirow{2}{*}{ Component } & \multicolumn{3}{|c|}{ Initial Eigen values } & \multicolumn{3}{|c|}{$\begin{array}{l}\text { Extraction Sums of Squared } \\
\text { Loadings }\end{array}$} & \multicolumn{3}{|c|}{ Rotation Sums of Squared Loadings } \\
\hline & Total & $\begin{array}{c}\% \text { of } \\
\text { Variance }\end{array}$ & Cumulative \% & Total & $\begin{array}{c}\% \text { of } \\
\text { Variance }\end{array}$ & Cumulative \% & Total & $\begin{array}{c}\% \text { of } \\
\text { Variance }\end{array}$ & Cumulative $\%$ \\
\hline 1 & 5.801 & 58.008 & 58.008 & 5.801 & 58.008 & 58.008 & 4.265 & 42.652 & 42.652 \\
\hline 2 & 1.905 & 19.046 & 77.053 & 1.905 & 19.046 & 77.053 & 3.333 & 33.329 & 75.982 \\
\hline 3 & 1.570 & 15.705 & 92.758 & 1.570 & 15.705 & 92.758 & 1.678 & 16.777 & 92.758 \\
\hline 4 & .492 & 4.920 & 97.678 & & & & & & \\
\hline 5 & .232 & 2.322 & 100.000 & & & & & & \\
\hline 6 & 1.502 & 1.502 & 100.000 & & & & & & \\
\hline 7 & -1.752 & -1.752 & 100.000 & & & & & & \\
\hline 8 & -2.002 & -2.002 & 100.000 & & & & & & \\
\hline 9 & -9.272 & -9.272 & 100.000 & & & & & & \\
\hline 10 & -1.362 & -1.362 & 100.000 & & & & & & \\
\hline
\end{tabular}

Table 3. Rotated Component Matrix (a)

\begin{tabular}{|c|c|c|c|}
\hline & \multicolumn{3}{|c|}{ Component } \\
\hline & 1 & 2 & 3 \\
\hline Market value of the vehicle & .156 & .932 & .068 \\
\hline Vehicle price range within market value & .928 & .011 & -.122 \\
\hline Vehicle design and structure & .558 & .605 & .204 \\
\hline Low-fuel consumption engine. & .576 & -.054 & .764 \\
\hline Mileage of the vehicle. & .778 & .572 & .251 \\
\hline Knowledge of the employee about the vehicle. & -.580 & -.782 & .178 \\
\hline Knowledge of the employee about the other surviving products. & .019 & .984 & -.085 \\
\hline Promise fulfillment by the company. & .958 & .192 & -.054 \\
\hline Cordial relationship between customer and company. & .234 & -.020 & -.955 \\
\hline Customer satisfaction. & .908 & .389 & .126 \\
\hline
\end{tabular}


After the correlation, we found the followings,

- Customer satisfaction and promise fulfillment: Correlation was highly significant at .957

- Customer satisfaction and knowledge level of employee : Correlation was low significant at $\mathbf{8 1 5 .}$
- Customer satisfaction and Vehicle market value : Correlation was significant at .529

- Customer satisfaction and price of the vehicle : Correlation was highly significant at .807

- Market value of the vehicle and price of the vehicle : Correlation was not significant(.170)

Table 4. Correlations

\begin{tabular}{|c|c|c|c|c|c|c|c|}
\hline & & QS1 & QS2 & QS3 & QS6 & QS8 & QS10 \\
\hline \multirow[t]{3}{*}{ QS1 } & Pearson Correlation & 1 & .170 & $.570\left(^{* *}\right)$ & $-.785\left(^{* *}\right)$ & $.358\left(^{* *}\right)$ & $.529(* *)$ \\
\hline & Sig. (2-tailed) & & .098 & .000 & .000 & .000 & .000 \\
\hline & $\mathrm{N}$ & 96 & 96 & 96 & 96 & 96 & 96 \\
\hline \multirow[t]{3}{*}{ QS2 } & Pearson Correlation & .170 & 1 & $.628\left({ }^{* *}\right)$ & $-.520\left(^{* *}\right)$ & $.843(* *)$ & $.807\left({ }^{* *}\right)$ \\
\hline & Sig. (2-tailed) & .098 & & .000 & .000 & .000 & .000 \\
\hline & $\mathrm{N}$ & 96 & 96 & 96 & 96 & 96 & 96 \\
\hline \multirow[t]{3}{*}{ QS3 } & Pearson Correlation & $.570\left(^{* *}\right)$ & $.628(* *)$ & 1 & $-.725\left(^{* *}\right)$ & $.530(* *)$ & $.718\left(^{* *}\right)$ \\
\hline & Sig. (2-tailed) & .000 & .000 & & .000 & .000 & .000 \\
\hline & $\mathrm{N}$ & 96 & 96 & 96 & 96 & 96 & 96 \\
\hline \multirow[t]{3}{*}{ QS6 } & Pearson Correlation & $-.785(* *)$ & $-.520(* *)$ & $-.725\left(^{* *}\right)$ & 1 & $-.730\left(^{* *}\right)$ & $-.815(* *)$ \\
\hline & Sig. (2-tailed) & .000 & .000 & .000 & & .000 & .000 \\
\hline & $\mathrm{N}$ & 96 & 96 & 96 & 96 & 96 & 96 \\
\hline \multirow[t]{3}{*}{ QS8 } & Pearson Correlation & $.358(* *)$ & $.843\left({ }^{* *}\right)$ & $.530\left(^{* *}\right)$ & $-.730\left(^{* * *}\right)$ & 1 & $.957\left({ }^{* *}\right)$ \\
\hline & Sig. (2-tailed) & .000 & .000 & .000 & .000 & & .000 \\
\hline & $\mathrm{N}$ & 96 & 96 & 96 & 96 & 96 & 96 \\
\hline \multirow[t]{3}{*}{ QS10 } & Pearson Correlation & $.529(* *)$ & $.807(* *)$ & $.718\left(^{* *}\right)$ & $-.815\left(^{* *}\right)$ & $.957\left(^{* *}\right)$ & 1 \\
\hline & Sig. (2-tailed) & .000 & .000 & .000 & .000 & .000 & \\
\hline & $\mathrm{N}$ & 96 & 96 & 96 & 96 & 96 & 96 \\
\hline
\end{tabular}

** Correlation is significant at the 0.01 level (2-tailed).

Table 5

\begin{tabular}{|c|c|c|c|c|c|c|c|c|c|c|}
\hline \multirow[b]{3}{*}{$\begin{array}{c}\text { FACTOR } \\
\mathrm{S}\end{array}$} & \multicolumn{10}{|c|}{ Customer Responds towards the factors in current Emerging Market } \\
\hline & \multicolumn{2}{|c|}{ Strongly Agree } & \multicolumn{2}{|c|}{ Agree } & \multicolumn{2}{|c|}{ Neutral } & \multicolumn{2}{|c|}{ Disagree } & \multicolumn{2}{|c|}{ Strongly Disagree } \\
\hline & $\begin{array}{c}\text { No. of } \\
\text { respondent } \\
\text { s } \\
\mathrm{N}=96\end{array}$ & $\begin{array}{l}\text { Percentag } \\
\text { e }(100 \%)\end{array}$ & $\begin{array}{c}\text { No. of } \\
\text { respondent } \\
s \\
\mathrm{~N}=96\end{array}$ & $\begin{array}{l}\text { Percentag } \\
\text { e (100\%) }\end{array}$ & $\begin{array}{c}\text { No. of } \\
\text { responden } \\
\text { ts } \\
\mathrm{N}=96\end{array}$ & $\begin{array}{c}\text { Percentage } \\
(100 \%)\end{array}$ & $\begin{array}{c}\text { No. of } \\
\text { respondent } \\
\mathrm{s} \\
\mathrm{N}=96\end{array}$ & $\begin{array}{l}\text { Percentag } \\
\text { e }(100 \%)\end{array}$ & $\begin{array}{c}\text { No. of } \\
\text { respondent } \\
s \\
\mathrm{~N}=96\end{array}$ & $\begin{array}{l}\text { Percentag } \\
\text { e }(100 \%)\end{array}$ \\
\hline QS1 & 32 & 33 & 40 & 42 & 24 & 25 & 0 & 0 & 0 & 0 \\
\hline QS2 & 8 & 8 & 32 & 33 & 32 & 33 & 0 & 0 & 24 & 25 \\
\hline QS3 & 0 & 0 & 24 & 25 & 32 & 33 & 24 & 25 & 16 & 17 \\
\hline QS4 & 0 & 0 & 16 & 17 & 24 & 25 & 56 & 58 & 0 & 0 \\
\hline QS5 & 0 & 0 & 48 & 50 & 8 & 8 & 40 & 42 & 0 & 0 \\
\hline QS6 & 48 & 50 & 32 & 33 & 16 & 17 & 0 & 0 & 0 & 0 \\
\hline QS7 & 16 & 17 & 56 & 58 & 24 & 25 & 0 & 0 & 0 & 0 \\
\hline QS8 & 0 & 0 & 48 & 50 & 24 & 25 & 0 & 0 & 24 & 25 \\
\hline QS9 & 32 & 33 & 64 & 67 & 0 & 0 & 0 & 0 & 0 & 0 \\
\hline QS10 & 0 & 0 & 48 & 50 & 8 & 8 & 16 & 17 & 24 & 25 \\
\hline
\end{tabular}

In the customer satisfaction point of view, all the factors were significant but their values were totally differing from each other. According to the significant values, promise fulfillment by the company, market value of the vehicle and price of the vehicle were highly significant. But the knowledge of the employee about the vehicle has very poor significant value. This showed that, the knowledge management was the very essential factor for the current market state.
- Knowledge of the employee about particular vehicle and customer satisfaction: Correlaration was low significant at .815 level.

- Knowledge of the employee and vehicle market value : Correlation was low significant level at .785

- Knowledge of the employee and price of the vehicle within market value : Correlation was low significant at .520

- Knowledge of the employee and the design of vehicle 
: Correlation was low significant at .725

In the knowledge management point of view, all the factors have very poor significant values and it was not enough to survive in the emerging marketing. This proved that, all the factors were inter-related with the knowledge management, especially customer satisfaction which showed very low value.

\section{Findings}

On the basis of this study, we found the results in accordance with the statements. All the data were tabulated and we provide the analysis report. From the table it clearly showed that the followings,

o The percentages of respondents are highly satisfied with the factors.

o The percentages of respondents are satisfied with the factors.

o The percentages of respondents have no opinion about the factors.

o The percentages of respondents who are not satisfied with the factors.

o The percentages of respondents are highly unsatisfied with the factors.

1. Only 32 percentages of respondents are highly satisfied with the Market value of the vehicle, 40 percentages of respondents are satisfied with the factor, no respondents are unsatisfied with the factor and 25 percentages of people have no opinion for the above statement.

2. Only 8 percentages of respondents are highly satisfied with the Vehicle price range within market value, 33 percentages of respondents are satisfied with the factor, 25 percentages respondents are highly unsatisfied with the factor and 33 percentages of people have no opinion for the above statement.

3. For Design of the vehicle, only 25 percentages of respondents are highly satisfied with the factor, 42 percentages of respondents are unsatisfied with the factor and 33 percentages of people have no opinion for the above statement.

4. Only 17 percentages of respondents are satisfied with the Low-fuel consumption engine, 58 percentages of respondents are unsatisfied with the factor and 25 percentages of people have no opinion for the above statement.

5. Only 50 percentages of respondents are highly satisfied with the Mileage of the vehicle, 42 percentages of respondents are unsatisfied with the factor and 8 percentages of people have no opinion for the above statement.

6. 50 percentages of respondents are highly satisfied with the Knowledge of the employee about the vehicle, 33 percentages of respondents are satisfied with the factor, no respondents are unsatisfied with the factor and 17 percentages of people have no opinion for the above statement.

7. Only 17 percentages of respondents are satisfied with the Knowledge of the employee about the other surviving products, 58 percentages of respondents are satisfied with the factor, no respondents are unsatisfied with the factor and 25 percentages of people have no opinion for the above statement.

8. Only 33 percentages of respondents are highly satisfied with the Cordial relationship between customer and company, 67 percentages of respondents are satisfied with the factor, no respondents are unsatisfied with the factor.

\section{Suggestions}

On the basis of this study, we provide the following suggestions for the employee to survive in the emerging marketing environment.

- They should have enough knowledge about the product.

- It should be instructed that the company should give proper training to the employee for their better performance.

- The employee should have the updated knowledge about the competing products.

- They should also improve their soft skills.

- The company should encourage the cordial relationship between the employee and the customer.

- $\quad$ They should be very careful not only in sales and also in customer satisfaction.

- $\quad$ The company should know the customer's requirement by meeting them in regular interval.

\section{CONCLUSION}

The organization should survive in the competitive business world by monitoring the other organizations and also improving the better knowledge management. Changing HR strategy in marketing definitely improves the growth by continual knowledge development. Main purpose of the paper is to realize the needed situation of Knowledge management in automotive industry. Statistical evidence supports the view that the knowledge management will improve the marketing capability of the employee and also customer satisfaction. It will be used to improve the efficiency of human resources practices in marketing and better performance. Based on the customer requirement the importance level of knowledge management is clearly stated out in this research work.

\section{REFERENCES}

Abu Rumman Et Al., (2019) Organizational Memory, Knowledge Management, Marketing Innovation and Cost Of Quality: Empirical Effects From Construction Industry In Jordan. Academy of Entrepreneurship Journal, 25, 1528-2686.

Al, A. S. A., Singh, S. K., Balasubramanian, S., \& Gaur, S. S. (2019). Employee Perception of Impact of Knowledge Management Processes on Public Sector Performance. Journal of Knowledge Management, 23(2), 351-373. Https://Doi.Org/10.1108/JKM-08-2017-0348

Al-Ajami, A. S. Z., \& Ayed Al-Qa'eed, M. (2020). The Impact of Knowledge Management on The Marketing Performance of Small and Medium Enterprises in The 
State of Kuwait. Modern Applied Science, 14(6), 21. Https://Doi.Org/10.5539/Mas.V14n6p21

Andrew, P (2010) What Executives Make of Innovation, Bloomberg Businessweek, April.

Chang, R (2008) Tata Nano: The World's Cheapest Car, The New York Times, January.

Drucker, P (2001) The Essential Drucker: Best of Sixty Years of Peter Drucker's Essential writings On Management, Harper Collins. New York.

Festa, G., Rossi, M., Kolte, A., \&t Situm, M. (2020). Territory-Based Knowledge Management in International Marketing Processes - The Case Of "Made in Italy" Smes. European Business Review, 32(3), 425-442. Https://Doi. Org/10.1108/EBR-06-2019-0129

H Al-Dmour, H., Asfour, F., Al-Dmour, R., \& AlDmour, A. (2020). The Effect of Marketing Knowledge Management on Bank Performance Through Fintech Innovations: A Survey Study of Jordanian Commercial Banks. Interdisciplinary Journal of Information, Knowledge, And Management, 15, 203-225. Https:// Doi.Org/10.28945/4619

Innovation in Emerging Markets (2007) Annual by Deloitte's Global Manufacturing Industry Group.

K.Karthikeyan \&t R. Rengaraj Alias Muralidharan International Journal Of Information Technology And Knowledge Management July-December (2010), Volume 2, No. 2, Pp. 627-631.

Lomas, L. M. (N.D.). Business-To-Business Marketing Perceptions: Customer Knowledge Management and Customer Engagement. 124.

Massingham, P., \&t Pomering, A. (2017). Introducing Knowledge Management to The Marketing Mix. Faculty of Business - Papers (Archive), 626-629.

Mckinsey (2005). Vision 2015 For the Indian Automotive Components Industry, Automotive Component

Migdadi, M. M. (2020). Knowledge Management, Customer Relationship Management and Innovation Capabilities. Journal of Business \& Industrial Marketing, Ahead-Of-Print (Ahead-Of-Print). Https://Doi. Org/10.1108/JBIM-12-2019-0504

Ministry of Heavy Industries and Public Enterprises (2006). Report of Working Group on Automotive Industry for The Eleventh Five-Year Plan, New Delhi.

Muddaha, G., \&t Kheng, Y. K. (2018). Impact of Marketing Knowledge Management on Marketing Innovation Empirical Evidence from Nigerian Smes. 18.
Narayanan, K. (2004). Technology Acquisition and Growth of Firms: Indian Automobile Sector Under Changing Policy Regimes, Economic and Political Weekly, 39(6), Pp. 461-470.

Narayanan, K. (2006). Technology Acquisition and Export Competitiveness: Evidence from Indian Automobile

Ryans, A. (2010). When Companies Underestimate LowCost Rivals, Mckinsey Quarterly, June.

Sala-I-Martin, X., Blanke, J., Drzeniek-Hanouz, M. Et Al., (2008). The Global Competitiveness Index: Prioritizing the Economic Policy Agenda, The Global Competitiveness Report 2008-2009, Geneva, Switzerland.

Sanjana Kaushik, M. G. (2020). A Critical Literature Review on Talent Management: A Research Agenda for the IT Workforce. Journal of the Social Sciences, 48(4), 1404-1417.

Scott, A., Christensen, C. (2004). Forging Innovation from Disruption, Information Week, August 1.

SIAM (2006). The Indian Automobile Industry: Statistical Profile 2005-06. Society of Indian Automobile Manufacturers, New Delhi.

Singh, D. K. A., \&t Madan, A. (2020). Marketing Analytics for Discerning the Buyers of India. 20. Journal of the Social Sciences,48 (3), 2144-2162

Sumantran, V. (2006). The Indian Auto Industry and The Role of Dealers, A Presentation at Federation of Indian Automobile Dealers.

The Mckinsey Quarterly, (2006). An Executive Take on The Top Business Trends: A Global Mckinsey Survey, April.

Zebal, M., Ferdous, A., \&t Chambers, C. (2019). An Integrated Model of Marketing Knowledge - A Tacit Knowledge Perspective. Journal of Research in Marketing and Entrepreneurship, 21(1), 2-18. Https:// Doi.0rg/10.1108/JRME-03-2018-0018

\section{Websourses}

https://www.emerald.com/insight/content/doi/10.1108/ JKM-08-2017-0348/full/html

https://www.emerald.com/insight/content/doi/10.1108/ EBR-06-2019-0129/full/html http://www.uq.edu.au/economics/ http://www.businessweek.com/interactive_reports/ most_innovative.html 